\title{
SINTESIS METIL ESTER DARI MINYAK DEDAK PADI MENGGUNAKAN KATALIS KALIUM DENGAN PENGEMBAN ZEOLIT ALAM
}

\author{
Arif Hidayat ${ }^{1}$, Septya Chilya Faizah $^{2}$, Resita Trisnaningtyas ${ }^{3}$ \\ Jurusan Teknik Kimia, Fakultas Teknologi Industri, Universitas Islam Indonesia ${ }^{1,2,3)}$ \\ Jl Kaliurang Km. 14,5, Sleman, Yogyakarta 55584 \\ E-mail : arif.hidayat@uii.ac.id
}

\begin{abstract}
Biodiesel is an alternative renewable energy source having many advantages such as environmental friendly, non-toxic, and has lower emission gases. Biodiesel is produced from transesterification of vegetable oils or animal fat. In this research, the transesterification of rice barn oil (RBO) using the solid base catalyst was studied. The performances of the catalysts were evaluated in terms of the reaction temperatures, the molar ratios of methanol to oil, and the catalyst loading. The effects of the mass ratio of catalyst to oil (1-10\%), the molar ratio of methanol to oil (6:1-12:1), and the reaction temperature $\left(40-60^{\circ} \mathrm{C}\right.$ ) were studied for the yield of biodiesel to optimize the reaction conditions. The results showed that the optimal conditions were a methanol to oil molar ratio of 12:1, the amount of catalyst of $10 \% \mathrm{wt}$. of oil, and reaction temperature of $60{ }^{\circ} \mathrm{C}$. The physicocharacteristics of the catalysts were analyzed by Nitrogen gas adsorption, surface functional groups by Fourier transform infrared spectroscopy (FT-IR), X-Ray Fluorescence Spectroscopy (XRF), and XRay Diffraction (XRD).
\end{abstract}

Key words: Biodiesel, Transesterification, Rice Barn Oil, Natural Zeolite.

\section{PENDAHULUAN}

Biodiesel adalah bahan bakar alternatif yang merupakan bahan bakar mesin diesel yang dapat dibuat dari minyak yang dapat diperbaharui seperti minyak nabati dan hewani yang ramah lingkungan yang memiliki keunggulan tidak beracun, secara esensial bebas sulfur dan benzena yang karsinogenik. Biodiesel dibuat dari trigliserida - trigliserida dan asam - asam lemak dari seperti minyak nabati dan hewani dengan reaksi kimia yang di sebut transesterifikasi dan esterifikasi.

Selama ini sintesis biodiesel menggunakan katalis homogen. Katalis ini memiliki beberapa kerugian dalam penggunaannya seperti sulitnya pemisahan produk dengan katalis, menghasilkan limbah yang berbahaya bagi lingkungan karena katalis sisa tidak dapat dipakai kembali, serta sulitnya penanganan dan penyimpanan. Alternatif yang dapat dipakai adalah penggunaan katalis padat (heterogen). Katalis heterogen memiliki keunggulan dalam hal proses permisahan setelah reaksi yang lebih mudah, keaktifan tinggi, dapat dipakai berulang kali dan usia pakai (lifetime) yang tinggi, dan lebih ramah lingkungan.

Zeolit alam sangat baik dan umum digunakan sebagai bahan katalis heterogen. Zeolit mempunyai sifat penting yang tidak ditemukan pada katalis amorf tradisional. Zeolit memiliki luas permukaan internal yang besar, stabilitas termal, dan mempunyai sifat asam dengan keberadaan situs Bronstead dan Lewis pada permukaannya. Faktor penting lain yang menentukan sifat zeolit dalam katalisis antara lain kemampuan adsorpsi terhadap senyawa reaktan. Zeolit dengan ukuran pori yang spesifik memiliki sifat selektif dalam mengadsorpsi molekul. Suatu molekul dapat teradsorpsi secara baik pada rongga zeolit apabila ukuran dan bentuk molekul tersebut sesuai dengan ukuran dan bentuk rongga dalam zeolit. Dalam proses katalisis, sifat ini akan menghasilkan selektivitas katalisis yang tinggi.

Zeolit adalah kristal alumina silika tiga dimensi dengan rumus molekul $\mathrm{xM}_{2} / \mathrm{nO} \cdot \mathrm{xAl}_{2} \mathrm{O}_{3} \cdot \mathrm{ySiO}_{2} \cdot \mathrm{wH}_{2} \mathrm{O}$ dimana $\mathrm{M}$ 
adalah kation yang merupakan logam golongan IA dan IIA dan w adalah jumlah air yang terkandung dalam pori - pori zeolit. Pembentuk dasar kristal zeolit adalah tetrahedral alumina silika $\mathrm{SiO} 4$ dan $\mathrm{AlO} 4$. Zeolit terbentuk dari ikatan dua tetrahedron secara bersama - sama, sehingga secara tiga dimensi terbentuk jaringan anionik dimana setiap oksigen dalam tetrahedron digunakan bersama antar tetrahedron sehingga satu oksigen untuk 4 tetrahedron. Hal ini menyebabkan oksigen dalam zeolit tidak ada yang tidak terikat dalam jaringan. Untuk setiap Si (bervalensi 5) yang diganti oleh $\mathrm{Al}$ (valensi 3), dihasilkan muatan negatif sehingga secara elektrokimia kemudian ternetralkan oleh adanya kation. Akibatnya, jaringan zeolit yang terbuka memungkinkan terikatnya kation - kation, begitu juga molekul air. Kation di dalam jaringan zeolit mudah tergantikan karena tidak terikat secara kuat. Struktur tiga dimensi zeolit menunjukkan dimensi molekular jaringan dengan luas permukaan yang besar.

Zeolit merupakan salah satu katalis yang banyak digunakan di industri, hal ini dikarenakan beberapa alasan yaitu (Corma, 1997) : (1) Zeolit mempunyai luas permukaan dan kapasitas adsorpsi yang sangat tinggi. (2) sifat adsorpsinya yang dapat dikontrol, dan dapat menjadi materi yang hidrofobik ataupun hidrofilik. (3) mempunyai active site yang bersifat asam yang dapat ditingkatkan sesuai dengan kegunaannya. (4) ukuran pori - pori yang bervariasi dapat digunakan sesuai dengan tujuannya.

Biodiesel adalah bahan bakar alternatif yang merupakan bahan bakar mesin diesel yang dapat dibuat dari minyak yang dapat diperbaharui seperti minyak nabati dan hewani yang ramah lingkungan yang

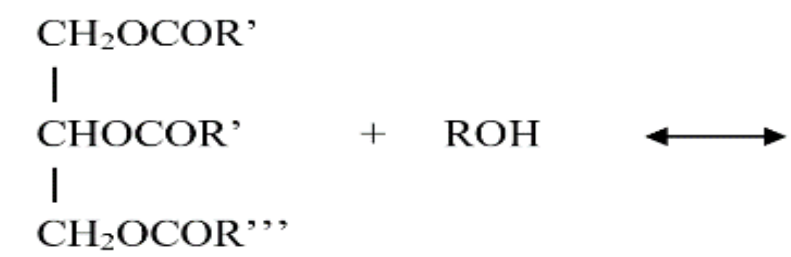

\footnotetext{
minyak atau lemak alkohol gliserol metil ester (biodiesel)

Gambar 1. Reaksi Transesterifikasi Trigliserida dengan Alkohol.
} esensial bebas sulfur dan benzena yang karsinogenik. Biodiesel dibuat dari trigliserida - trigliserida dan asam - asam lemak dari seperti minyak nabati dan hewani dengan reaksi kimia yang di sebut transesterifikasi dan esterifikasi.

Transesterifikasi yaitu proses kimiawi yang mempertukarkan grup alkoksi pada senyawa ester dengan alkohol. Transesterifikasi merupakan reaksi pemindahan alkohol dari suatu ester oleh alkohol lain yang meliputi rangkaian tiga reaksi reversibel yang berurutan. Pertama adalah konversi trigliserida menjadi digliserida, diikuti dengan konversi digliserida menjadi monogliserida dan yang terakhir monogliserida menjadi gliserin. Tiap tahap menghasilkan satu molekul ester. Senyawa ester, pada tingkat (grade) tertentu inilah yang menjadi biodiesel. Sintesa biodiesiel melalui reaksi transesterifikasi antara minyak dengan alkohol dapat dilihat pada gambar 1 .

Beberapa jenis minyak nabati seperti : kelapa sawit (Baroutian et al., 2010), jarak pagar (Tiwari et al., 2007), kedelai (Xie and Li, 2006), bunga matahari (Arzamendi et al., 2008), dan kelapa (Benjapornkulaphong et al., 2009) telah dipelajari sebagai bahan baku untuk produksi biodiesel. Namun yang menjdai perhatian utama dalam produksi biodiesel adalah harga minyak nabati lebih mahal jika dibandingkan dengan bahan bakar diesel yang berbasis bahan bakar fosil. Hal ini mengakibatkan dibeberapa negara, minyak jarak atau jelantah banyak digunakan sebagai bahan baku karena harganya yang lebih rendah dibandingkan dengan bahan bakar diesel yang berbasis bahan bakar fosil.

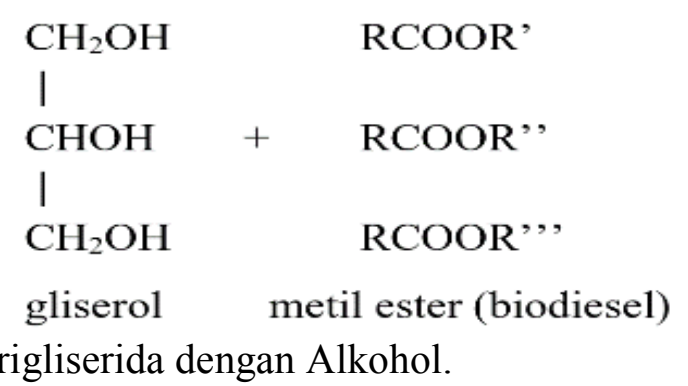


Disamping itu pencampuran biodiesel dengan solar adalah pilihan lain untuk mengurangi tingginya harga biodiesel.

Beberapa peneliti telah mempelajari pemakaian katalis padat untuk reaksi transesterifikasi minyak nabati. Beberapa jenis katalis padat yang telah diteliti untuk kepentingan reaksi transesterifikasi antara lain : kompleks logam (Abreu et al., 2003), logam oksida seperti oksida kalsium $(\mathrm{CaO})$ (Granados et al., 2007), oksida magnesium (MgO) (Wang dan Yang, 2007), oksida zirkonium $\left(\mathrm{ZrO}_{2}\right)$ (Jitputti et al., 2006). Disamping itu beberapa jenis pengemban (support) juga telah diteliti untuk kepentingan katalis pada reaksi transesterifikasi. Katalis padat tidak dikonsumsi atau dilarutkan dalam reaksi, oleh karena itu pada akhir reaksi katalis dapat dengan mudah dipisahkan dari produk. Dengan demikian produk tidak mengandung sisa katalis dan biaya pemisahan produk akan dapat dikurangi. Katalis juga dapat diregenerasi dan digunakan kembali, di samping itu reaksi lebih ramah lingkungan karena tidak diperlukan larutan asam atau air pada langkah pemisahan produk (Dossin et $a l .$, 2006).

Beberapa jenis oksida, diantaranya logam alkali tanah dan logam transisi telah dipelajari untuk proses transesterifikasi minyak nabati. Struktur logam oksida terdiri atas ion positif (kation) yang memiliki asam Lewis dan ion oksigen yang negatif (anion) yang memiliki basa Bronsted. Pada proses metanolisis, keberadaan situs BronstedLewis menyediakan situs aktif penyerapan untuk metanol, dimana ikatan $\mathrm{O}-\mathrm{H}$ akan mudah untuk terputus dan terbentuk anion metoksida dan kation hidrogen. Anion metoksida kemudian akan bereaksi dengan molekul trigliserida membentuk metil ester.

Diantara golongan alkali tanah Magnesium oksida $(\mathrm{MgO})$ merupakan jenis oksida logam yang memiliki kekuatan basa yang paling lemah dan kelarutan yang rendah dalam alkohol, sehingga jarang digunakan untuk produksi biodiesel. Magnesium oksida dapat diperoleh dari pemanasan langsung dari magnesium karbonat atau magnesium hidroksida memiliki kekuatan dasar yang paling lemah dan kelarutan dalam metanol di antara kelompok II oksida dan telah jarang digunakan untuk produksi biodiesel. Wang et al. (2007) telah mempelajari pemakaian katalis $\mathrm{MgO}$ untuk reaksi transesterifikasi minyak kedelai dengan metanol dalam keadaan superkritis. Hasil penelitian menunjukkan setelah waktu reaksi 10 menit diperoleh konversi 99\%. Kondisi operasi reaksi esterifikasi dijalankan pada suhu 523 ${ }^{\circ} \mathrm{C}$ dan tekanan $24 \mathrm{MPa}$. Dari penelitian dapat disimpulkan bahwa aktivitas katalis akan meningkat pada suhu dan tekanan yang lebih tinggi.

Granados et al. (2007) dalam penelitiannya menggunakan $\mathrm{CaO}$ yang sudah diaktivasi sebagai katalis basa padat untuk reaksi metanolisis minyak bunga matahari. Keaktifan katalis $\mathrm{CaO}$ dipengaruhi oleh kontak yang terjadi antara katalis dengan air dan gas $\mathrm{CO}_{2}$. Kinerja katalitik akan menurun setelah kontak dengan udara pada periode waktu tertentu, hal ini menunjukkan bahwa $\mathrm{CaO}$ dengan cepat terhidrasi dan terkarbonisasi di udara. Hal ini diperkuat dengan hasil analisis Infra Red (IR) yang menunjukkan puncak spesies $\mathrm{CaO}$ tidak terdeteksi setelah kontak dengan udara selama lebih dari 20 hari. Ini berarti bahwa situs permukaan aktif katalis $\mathrm{CaO}$ telah mengalami deaktivasi dengan keberadaan gas $\mathrm{CO}_{2}$ dan permukaan katalis ditutupi dengan $\mathrm{H}_{2} \mathrm{O}$. Untuk menghindari deaktivasi katalis, $\mathrm{CaO}$ dipanaskan pada suhu $700{ }^{\circ} \mathrm{C}$ dengan tujuan untuk menghilangkan $\mathrm{CO}_{2}$ yang teradsorbsi dipermukaan sebelum digunakan dalam reaksi. Setelah waktu reaksi 100 menit, dicapai konversi sebesar $94 \%$ yang diperoleh pada kondisi $60{ }^{\circ} \mathrm{C}$ dengan perbandingan molar alkohol dan minyak molar rasio 13:1 dan penggunaan katalis sebesar $3 \%$ berat. Katalis dapat digunakan sampai 8 kali reaksi sebelum terjadi deaktivasi. 
Peneliti lain, Demirbas (2007), mempelajari pengaruh keadaan superkritis untuk reaksi transesterifikasi minyak bunga matahari. Pada penelitiannya, digunakan katalis $\mathrm{CaO}$ yang mempunyai ukuran 60-120 mesh, perbandingan alkohol dan minyak 20:1, tekanan $24 \mathrm{MPa}$ dan jumlah katalis 3\% massa. Hasil penelitian menunjukkan konversi metil ester setelah 26 menit adalah $98,9 \%$.

\section{METODE PENELITIAN}

\subsection{Bahan dan Alat Penelitian}

Kalium Nitrat $\left(\mathrm{KNO}_{3}\right)$ (Merck), zeolit alam, larutan Asam Sulfat p.a. $\left(\mathrm{H}_{2} \mathrm{SO}_{4}\right)$ (Merck), aquadest, dan larutan Barium Hidroksida $\left(\mathrm{Ba}(\mathrm{OH})_{2}\right)$. Alat - alat yang digunakan : alat - alat gelas, thermometer, ayakan, lumpang porselin dan penggerus, oven, furnace, pengaduk magnet, kertas saring Whatman 42, $\mathrm{pH}$ universal, timbangan analit, Hotplate.

\subsection{Sintesis dan Karakterisasi Katalis}

Zeolit alam mula - mula digerus zeolit alam dalam lumpang porselen, kemudian diayak sampai ukuran 200 mesh. Selanjutnya dilakukan aktivasi zeolit alam dengan melarutkan 200 gr zeolit alam yang sudah diayak ke dalam $500 \mathrm{ml}$ larutan $\mathrm{H}_{2} \mathrm{SO}_{4} \quad 0,5$ $\mathrm{M}$ dan diaduk dengan stirer selama 4 jam pada suhu kamar. Setelah 4 jam, larutan didinginkan kemudian dilakukan penyaringan dengan kertas saring Whatman 42, dan dipisahkan antara padatan dan filtratnya. Filtrat kemudian dibuang, sedangkan padatan dicuci dengan aquadest hingga $\mathrm{pH}$ netral. Setelah $\mathrm{pH}$ netral, filtrat di cek dengan meneteskan $\mathrm{Ba}(\mathrm{OH})_{2}$. Apabila setelah ditetesi $\mathrm{Ba}(\mathrm{OH})_{2}$ terbentuk larutan keruh, penetralan dilanjutkan. Setelah padatan bebas sulfat yaitu tidak terbentuk larutan keruh pada filtrat setelah ditetesi $\mathrm{Ba}(\mathrm{OH})_{2}$, padatan kemudian dikeringkan dalam oven pada suhu $130^{\circ} \mathrm{C}$ selama 24 jam.
Sintesis katalis Kalium / zeolit alam aktivasi (K-ZAA) dilakukan dengan metode impregnasi dengan cara mencampurkan larutan Kalium dari $\mathrm{KNO}_{3}$ dengan zeolit alam berukuran 200 mesh dalam pelarut akuades. Pelarut dalam campuran diuapkan sehingga diperoleh padatan. Padatan hasil penguapan dikalsinasi dengan mengalirkan gas $\mathrm{N}_{2}$ pada temperatur $300{ }^{\circ} \mathrm{C}$ dan dilanjutkan dengan oksidasi dengan aliran gas $\mathrm{O}_{2}$ pada temperatur $300{ }^{\circ} \mathrm{C}$.

Material hasil sintesis kemudian dikarakterisasi dengan pengukuran kristanilitas menggunakan $X$-Ray Diffraction (XRD), penentuan luas permukaan dan distribusi ukuran pori dengan BET Surface Area Analyzer, analisis kandungan mineral dengan X-Ray Fluorescence Spectroscopy (XRF), analisis gugus fungsional dengan Fourier Transform Infrared (FT-IR) Spectrometry.

\subsection{Uji Aktivitas Katalis}

Uji aktivitas katalis K-ZAA dilakukan dengan melakukan reaksi transesterifikasi minyak dedak padi atau rice barn oil (RBO). RBO dengan volume tertentu dicampurkan dengan larutan metanol di dalam labu leher tiga. Selanjutnya ke dalam labu leher tiga ditambahkan katalis K-ZAA dengan massa tertentu. Kemudian campuran RBO, metanol dan katalis K-ZAA diaduk pada kecepatan tertentu selama 60 menit dengan suhu reaksi dijaga konstan. Biodiesel yang terbentuk kemudian dipisahkan untuk mengetahui konversi dan kualitas biodiesel yang diperoleh. Untuk penentuan keberhasilan reaksi transesterifikasi digunakan analisis perolehan atau yield biodiesel.

\section{HASIL PENELITIAN DAN PEMBAHASAN}

\subsection{Karakterisasi Katalis}

Luas permukaan spesifik, volume total pori dan rerata jejari pori katalis $\mathrm{K} / \mathrm{ZAA}$ ditentukan dengan metode analisis serapan gas. Hasil analisis ditampilkan dalam Tabel 2. Dari data pada tabel 2 terlihat bahwa pengembanan logam Kalium kepermukaan zeolit alam aktivasi menyebabkan penurunan 
Tabel 1. Hasil Karakterisasi Menggunakan Surface Area Analyzer.

\begin{tabular}{c|c|c}
\hline Karakter & ZAA & Katalis K/ZAA \\
\hline Luas permukaan spesifik $\left(\mathrm{m}^{2} / \mathrm{g}\right)$ & 188,3 & 82,97 \\
Volume Pori $\left(\mathrm{cm}^{3} / \mathrm{g}\right)$ & 0,2794 & 0,2105 \\
Rerata jejari pori $(\AA)$ & 20,51 & 26,72 \\
\hline
\end{tabular}

Tabel 2. Perbandingan Serapan Gugus Fungsional dari Zeolit Alam Aktivasi dan Katalis K/ZAA.

\begin{tabular}{c|c|c}
\hline ZAA & Katalis K/ZAA & Serapan gugus fungsional \\
\hline 3459,12 & 3465,48 & Vibrasi OH regang dari OH oktahedral dan atau $\mathrm{H}_{2} \mathrm{O}$ \\
1639,40 & 1642,14 & Vibrasi tekuk dari molekul air \\
1057,80 & 1051,75 & Regangan asimetris internal O-Si-O \\
794,89 & 794,34 & Regangan simetris internal O-Si-O \\
461,72 & 468,70 & Vibrasi tekuk Si-O-Si \\
\hline
\end{tabular}

luas permukaan spesifik dan volume total pori zeolit. Hal ini dimungkinkan terjadi oleh adanya pembentukan oksida kalium $\left(\mathrm{K}_{2} \mathrm{O}\right)$ pada permukaan zeolit alam aktivasi dalam mulut pori sehingga adsorpsi gas $\mathrm{N}_{2}$ terhalangi. Asumsi pembentukan oksida kalium didukung oleh adanya kenaikan ukuran rerata jejari pori.

Karakterisasi dengan menggunakan spektrofotometri infra merah (FTIR) dilakukan pada zeolit alam aktivasi dan katalis K/ZAA tersulfatasi untuk mengetahui apakah terjadi perubahan gugus fungsional pada permukaan zeolit. Perbandingan serapan karakteristik tersebut disajikan dalam tabel 2. Dari hasil analisis FTIR terlihat bahwa ada penurunan serapan $\mathrm{O}-\mathrm{H}$ regang pada katalis K/ZAA yang menunjukkan terjadinya dehidrasi akibat proses kalsinasi. Pada serapan vibrasi Al-O dan Si-O tidak ada perubahan bilangan gelombang yang signifikan. Hal ini mengindikasikan bahwa proses kalsinasi tidak merusak ikatan Al-O dan Si-O. Pita serapan pada bilangan gelombang 794,89 dan 793,33 $\mathrm{cm}^{-1}$ dari katalis K/ZAA merupakan regangan simetris eksternal O-Si$\mathrm{O}$ atau O-Al-O.

Selanjutnya vibrasi tekuk pada daerah bilangan gelombang 461,72 dan 468,70 $\mathrm{cm}^{-1}$ merupakan vibrasi tekuk Si-O-Si.

\subsection{Uji Aktivitas Katalis}

Keberhasilan pengembanan $\mathrm{K}_{2} \mathrm{O}$ pada zeolit dapat dibuktikan dengan pengukuran kandungan kalium pada zeolit tersebut, yaitu dengan menggunakan analisis XRF. Pada penelitian ini katalis kalium dibuat dengan cara mengimregnasikan logam Kalium ke permukaan zeolit. Dari hasil analisis XRF terlihat bahwa terjadi kenaikan kandungan logam Kalium yang cukup signifikan yaitu dari $0,1124 \%$ pada zeolit alam aktivasi menjadi $10,713 \%$ pada katalis K/ZAA. Peningkatan kandungan logam Kalium menunjukkan bahwa proses sintesis katalis Kalium relatif berhasil.

\subsubsection{Pengaruh Jumlah Katalis}

Untuk mempelajari pengaruh jumlah katalis terhadap aktivitas katalis $\mathrm{K} / \mathrm{ZAA}$, dilakukan serangkaian percobaan dengan melakukan variasi terhadap jumlah katalis yang ditambahkan pada campuran minyak dedak padi dan metanol. Nilai jumlah katalis yang dipelajari adalah $1 ; 2,5 ; 5$ dan $10 \%$ massa minyak dedak padi. Untuk setiap percobaan yang dijalankan, kondisi operasinya adalah suhu $60^{\circ} \mathrm{C}$, perbandingan molar metanol terhadap inyak dedak padi 6 : 1 dan kecepatan pengadukan $500 \mathrm{rpm}$. Hasil percobaan dapat dilihat pada gambar 2 . 


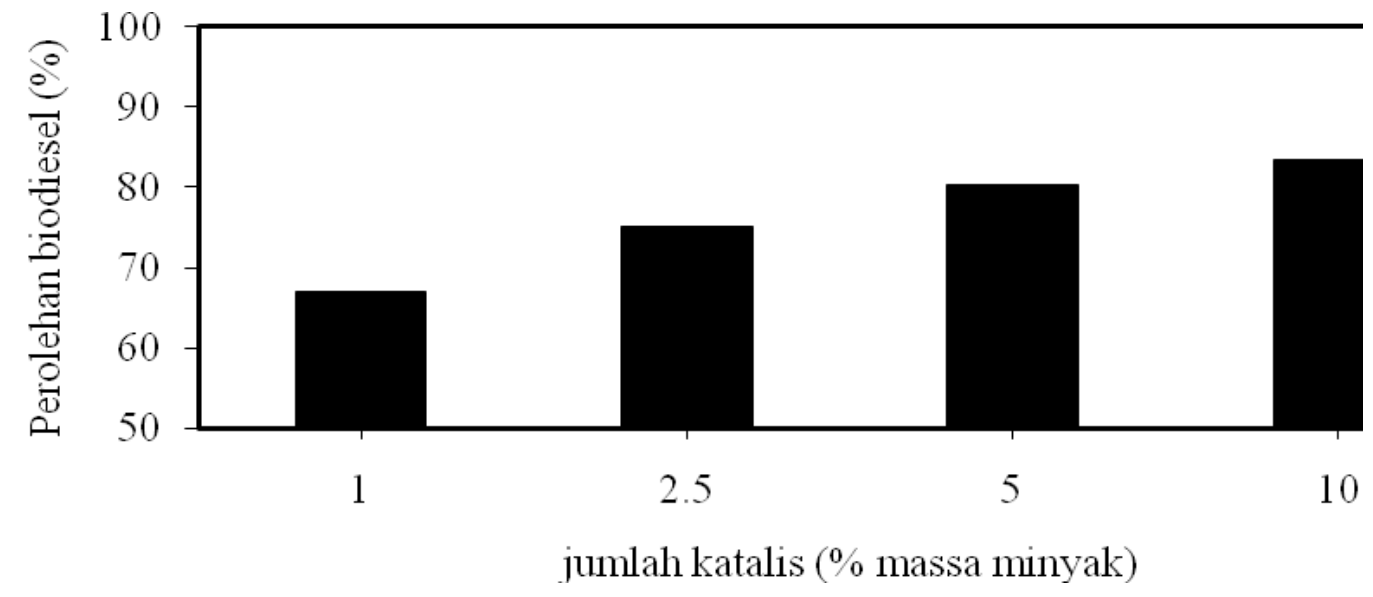

Gambar 2. Pengaruh Jumlah Katalis terhadap Perolehan Biodiesel pada Katalis K/ZAA.

Dari Gambar 2 terlihat bahwa dengan penambahan jumlah katalis berpengaruh terhadap perolehan biodiesel. Pada reaksi yang menggunakan katalis $\mathrm{K} / \mathrm{ZAA}$ terlihat bahwa pada jumlah katalis $1 \%$ massa minyak dedak padi nilai perolehan biodiesel yang diperoleh sebesar $64,9 \%$, selanjutnya perolehan biodiesel meningkat berturut turut menjadi 72,$7 ; 78,4$ dan $81,6 \%$ pada pemakaian jumlah katalis 2,5; 5 dan $10 \%$ massa minyak dedak padi. Dengan semakin besarnya jumlah katalis, reaksi berlangsung lebih cepat yang menghasilkan nilai perolehan biodiesel yang semakin tinggi. Adanya penambahan katalis menurunkan energi aktivasi yang mendorong reaksi berlangsung lebih cepat karena tumbukan antar molekul berlangsung lebih efektif. Jumlah katalis yang semakin banyak menambah jumlah situs aktif yang dapat diakses oleh molekul pereaktan. Jumlah situs aktif yang bertambah memperbesar peluang molekul dapat berinteraksi untuk memulai reaksi. Namun jumlah katalis yang diperbesar tidak berpengaruh terhadap konversi keseimbangan.

Dari Gambar 2 terlihat juga bahwa katalis K/ZAA menunjukkan aktivitas yang tinggi. Aktivitas yang tinggi dari katalis K/ZAA dapat dijelaskan berdasarkan dari hasil karakterisasi yang telah dilakukan. Katalis K/ZAA memiliki luas permukaan dan volum pori total yang besar. Luas permukaan dan volume pori total yang besar mampu mengakomodasi jumlah molekul pereaktan yang lebih banyak untuk berinteraksi dengan situs aktif sehingga lebih banyak molekul pereaktan yang bereaksi.

\subsubsection{Pengaruh Perbandingan Molar Pereaktan}

Reaksi trans esterifikasi secara stoikhiometris memerlukan 3 (satu) mol trigliserida dan 1 (satu) mol metanol. Namun reaksi trans esterifikasi merupakan reaksi yang dapat balik (reversible), sehingga reaksi dibatasi oleh kondisi keseimbangan. Untuk mendorong agar lebih banyak produk yang terbentuk, maka reaksi harus didorong menuju pada keseimbangan baru dengan cara menggeser reaksi ke arah pembentukan produk. Salah satu usaha untuk mendapatkan keseimbangan baru yang mengarah pada pembentukan produk, maka jumlah salah satu pereaksi dibuat berlebihan. Pada percobaan yang telah dilakukan, pengaruh perbandingan molar pereaktan ditinjau pada jumlah katalis $10 \%$ massa minyak dedak padi, suhu reaksi $60^{\circ} \mathrm{C}$ dan kecepatan pengadukan $500 \mathrm{rpm}$. Perbandingan molar metanol dengan minyak dedak padi divariasikan pada nilai $6: 1 ; 8: 1 ; 10: 1$ dan 12:1. Hasil percobaan dengan menggunakan katalis K/ZAA dapat dilihat pada gambar 3.

Seperti yang ditunjukkan pada Gambar 3 terlihat bahwa pada percobaan dengan menggunakan katalis K/ZAA, mula - mula nilai kon perolehan biodiesel pada 


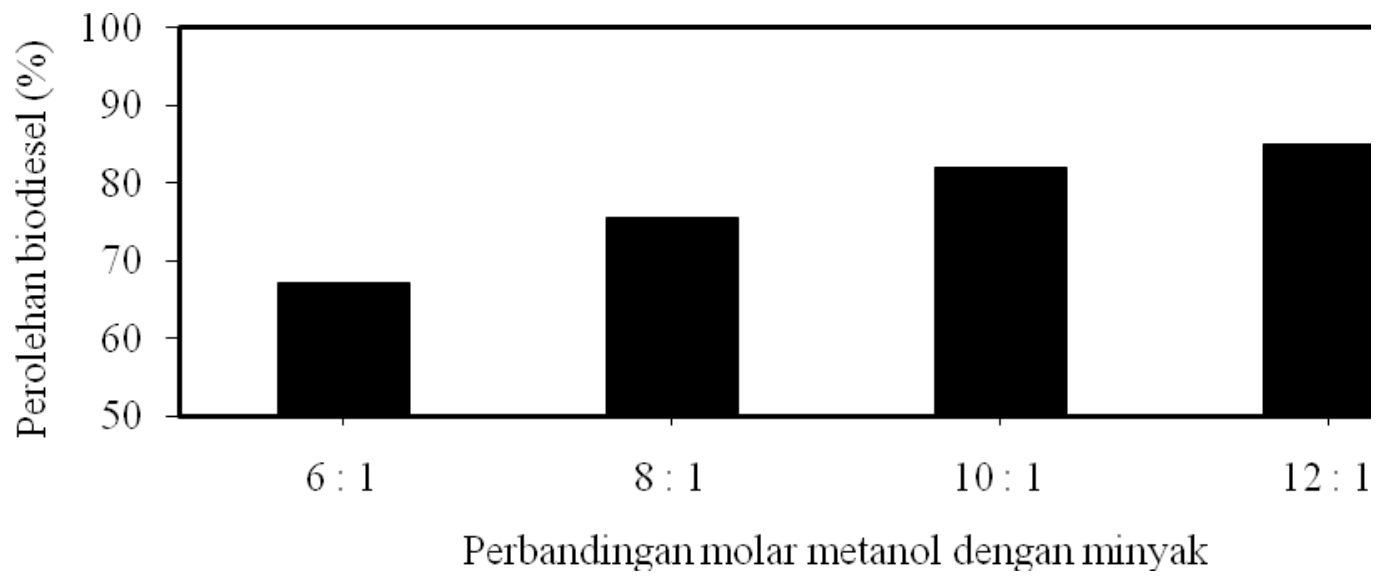

Gambar 3. Pengaruh Perbandingan Molar Metanol dengan Minyak Dedak padi terhadap Perolehan Biodiesel.

perbandingan molar metanol dengan minyak dedak padi adalah $61,4 \%$. Nilai perolehan biodiesel kemudian mengalami peningkatan menjadi 71,$2 ; 77,9$ dan $81,6 \%$ perbandingan molar metanol dengan minyak dedak padi berturut-turut $8: 1 ; 10: 1$ dan 12:1. Terlihat bahwa perolehan biodiesel mengalami kenaikan dengan semakin besarnya nilai perbandingan molar metanol dengan minyak dedak padi. Pada nilai perbandingan molar metanol dan pereaktan yang semakin besar, kecenderungan naiknya terlihat semakin kecil. Ketersediaan luas permukaan yang besar dan nilai keasaman yang tinggi akan berpengaruh terhadap nilai perolehan biodiesel.

Secara umum dapat dilihat bahwa pada kenaikan perbandingan molar metanol dengan minyak dedak padi memperbesar perolehan biodiesel. Hal ini sesuai dengan pernyataan prinsip Le Chatelier's. Prinsip Le Chatelier's menyatakan bahwa pada reaksi yang dibatasi oleh keseimbangan, maka untuk dapat mengubah keseimbangan ke arah terbentuknya produk maka usaha yang dapat dilakukan adalah dengan menambah jumlah mol pereaktan atau dengan mengurangi produk yang dihasilkan. Pada penelitian yang dilakukan secara batch, usaha untuk melakukan pengurangan produk relatif sulit dilakukan. Dengan demikian usaha yang dapat dilakukan untuk mengubah keseimbangan ke arah terbentuknya produk adalah dengan menambah jumlah mol pereaktan. Seperti yang telah dijelaskan di atas secara stoikhiometris jumlah mol metanol yang diperlukan adalah tiga kali jumlah mol trigliserida dalam minyak dedak padi. Maka usaha yang dilakukan adalah jumlah mol metanol yang dibuat sangat berlebihan.

\subsubsection{Pengaruh Suhu Reaksi}

Reaksi trans esterifikasi dapat terjadi pada suhu yang berbeda-beda, tergantung pada sifat fisik minyak, katalis maupun proses yang digunakan. Reaksitrans esterifikasi dapat dijalankan pada suhu kamar, suhu mendekati titik didihnya, suhu kritis maupun suhu super kritis. Untuk mempelajari pengaruh suhu terhadap perolehan biodiesel, dilakukan percobaan pada variasi suhu reaksi $\left(40,50\right.$ dan $\left.60^{\circ} \mathrm{C}\right)$, sedangkan kondisi proses yang lain dipertahankan (perbandingan molar metanol dengan minyak dedak padi $6: 1$, jumlah katalis $10 \%$ massa minyak dedak padi dan kecepatan pengadukan $500 \mathrm{rpm}$ ). Hasil percobaan dapat dilihat pada Gambar 4.

Dari gambar 4. dapat dilihat bahwa kenaikan suhu memberikan pengaruh yang signifikan terhadap kecepatan reaksi trans esterifikasi. Pada reaksi trans esterifikasi yang telah dilakukan, pemakaian katalis K/ZAA menunjukkan bahwa kenaikan suhu reaksi akan meningkatkan nilai perolehan 


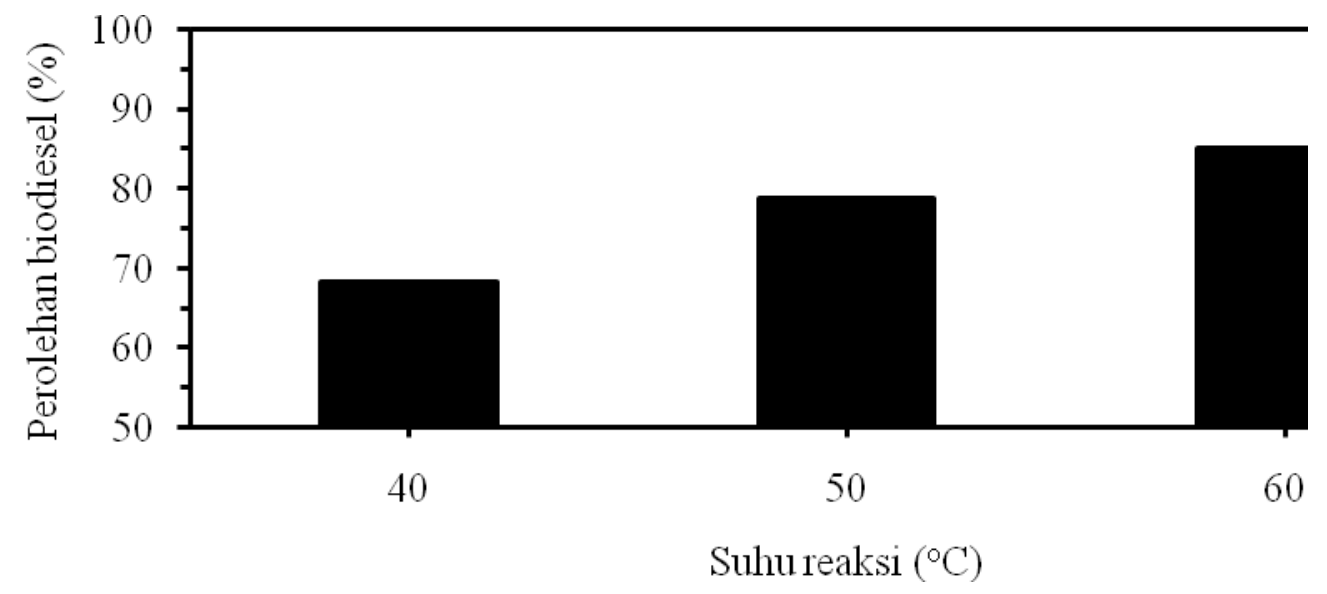

Gambar 4. Pengaruh Suhu Reaksi terhadap Perolehan Biodiesel.

biodiesel. Pada penggunaan katalis K/ZAA, nilai perolehan biodiesel meningkat dari 62,3 menjadi 73,5 dan $81,6 \%$ dengan kenaikan suhu dari $40^{\circ} \mathrm{C}$ menjadi 50 dan $60^{\circ} \mathrm{C}$.

Suhu merupakan parameter yang penting dalam meninjau kecepatan reaksi trans esterfikasi. Hal ini terutama terlihat pada reaksi yang melibatkan beberapa fase. Pada reaksi trans esterifikasi terbentuk dua fase yang tidak saling tercampur, yaitu fase minyak dan fase alkohol. Hal ini menyebabkan terjadinya hambatan perpindahan massa. Untuk meningkatkan kecepatan perpindahan massa diperlukan suhu yang lebih tinggi untuk dapat mengatasi hambatan perpindahan massa tersebut. Minyak memiliki kelarutan yang rendah di dalam alkohol, sehingga muncul hambatan perpindahan massa. Kenaikan suhu mendorong peningkatan kelarutan minyak di dalam metanol dan berdampak pada turunnya hambatan perpindahan massa. Di sisi lain, nilai kekentalan minyak menurun dengan naiknya suhu, hal ini menyebabkan pencampuran yang baik antara pereaktan dengan katalis. Sehingga pada suhu yang lebih tinggi, reaksi diharapkan dikontrol oleh reaksi kimia.

Dari segi kinetika, semakin tinggi suhu reaksi maka nilai tetapan kecepatan reaksi semakin besar sehingga menghasilkan kecepatan reaksi yang lebih tinggi dan konversi yang lebih besar.
Di samping itu dengan naiknya suhu, molekul - molekul pereaktan memperoleh tambahan energi. Tambahan energi yang diterima digunakan untuk menaikkan energi kinetik dalam bentuk gerakan molekul. Hal ini menyebabkan tumbukan antar molekul menjadi lebih sering. Tumbukan energi yang terjadi sebagian digunakan untuk memecahkan ikatan yang telah ada dan membentuk ikatan baru. Fenomena ini mendorong terjadinya reaksi kimia, di mana semakin banya terjadinya tumbukan meningkatkan kecepatan reaksi. Pada penelitian ini suhu reaksi dibatasi pada suhu $60^{\circ} \mathrm{C}$, hal ini dikarenakan suhu didih metanol adalah $68^{\circ} \mathrm{C}$. Apabila suhu reaksi melampaui titik didih, maka konsentrasi metanol pada fase cair berkurang sehingga menurunkan kecepatan reaksi trans esterifikasi dan perolehan biodiesel.

\section{KESIMPULAN}

Dari hasil penelitian dapat ditarik kesimpulan bahwa katalis K/ZAA dengan pengemban zeolit alam mampu untuk mengkatalis sintesis metil ester dari minyak dedak padi. Kandungan logam Kalium dalam zeolit alam, waktu reaksi dan suhu reaksi berpengaruh terhadap kemampuan reduksi katalis $\mathrm{K} / \mathrm{ZAA}$ dengan pengemban zeolit alam. 


\section{DAFTAR PUSTAKA}

Abreu F.R., Lima D.G., Hamu E.H., Einloft S., Rubim J.C., and Suarez P.A.Z., 2003, New metal catalysts for soybean oil transesterification, Journal of the American Oil Chemists Society, 80, 601-604.

Alsobaai A.M., Zakaria R., and Hameed B.H., 2007, Hydrocracking of petroleum gas oil over NiW/MCM48-USY composite catalyst, Fuel Processing Technology, 88, 9, 921928.

Arzamendi G., Campo I., Arguinarena E., Sanchez M., Montes M., and Gandia L. M., Synthesis of biodiesel from sunfloweroil with silica-supported $\mathrm{NaOH}$ catalysts, Journal of Chemical Technology and Biotechnology, 83, 862-870.

Baroutian S., Aroua M. K., Raman A. A. A., Sulaiman N. M. N., Potassium hydroxide catalyst supported on palm shell activated carbon for transesterification of palm oil, Fuel Processing Technology, 91 (11), 1378-1385.

Benjapornkulaphong,

S., Ngamcharussrivichai, C., Bunyakiat, K., 2009. Al2O3-supported alkali and alkali earth metal oxides for transesterification of palm kernel oil and coconut oil. Chemical Engineering Journal, 145, 468-474.

Chongkong S., Tongurai C., and Chetpattananondh P., 2009, Continuous esterification for biodiesel production from palm fatty acid distilate using economical proces, Renewable Energy, 31, 10591063.

Chouhan, A.P.S., and Sarma, A.K., 2011, Modern heterogeneous catalysts for biodiesel production: A comprehensive review, Renewable and Sustainable Energy Reviews, 15(9), 4378-4399.
Corma A., 1997, From Microporous to Mesoporous Molecular Sieve Materials and Their Use in Catalysis, Chemical Reviews, 97, 2373-2419.

Demirbas, A., 2007, Biodiesel from Sunflower Oil in Supercritical Methanol with Calcium Oxide. Energy Conversion and Management, 48, 937-941.

Dossin T. F., Reyniers M. F., Berger R. J., Marin G. B., 2006, Simulation of heterogeneously $\mathrm{MgO}$ - catalyzed transesterification for fine-chemical and biodiesel industrial production, Applied Catalysis B: Environmental, 67, 1-2, 136-148.

Freedman B., Pryde E.H., and Mounts T.L., 1984, Variables affecting the yields of fatty esters from transesterified vegetable oils, Journal of the American Oil Chemists Society, 61, 1638-1643.

Garcia C.M., Teixeira S., Marciniuk L.L, and Schuchardt U., 2008, Transesterification of soybean oil catalyzed by sulfated zirconia. Bioresource Technology, 99, 6608 6613.

Granados M.L., Poves M.D.Z., Alonso, R. Mariscal D.M., Galisteo F.C., Moreno- Tost R., Santamaria J., and Fierro J.L.G., 2007, Biodiesel from sunflower oil by using activated calcium oxide, Applied Catalysis B: Environmental, 73, 317-326.

Jitputti J., Kitiyanan B., Rangsunvigit P., Bunyakiat K., Attanatho L., and Jenvanitpanjakul P., 2006, Transesterification of crude palm kernel oil and crude coconut oil by different solid catalysts, Chemical Engineering Journal, 116, 61-66.

Kiss A.A., Dimian A.C., and Rothenberg G., 2006, Solid Acid Catalysts for Biodiesel Production - Towards Sustainable Energy, Advanced Synthesis \& Catalysis, 348, 75-81. 
Lugstein A., Jentys A., and Vinek H., 1999, Hydroisomerization and cracking of n-octane and $\mathrm{C} 8$ isomers on $\mathrm{Ni}$ containing zeolites, Applied Catalysis A: General, 176, 1, 119-128.

Lugstein, A., Jentys, A., and Vinek, H. 1997, Hydroconversion of n-Heptane over Co/Ni Containing HZSM-5, Applied Catalysis A: General, 152, 1,93-105.

Sayan S., Demirel B., and Paul J., 2007, Methyldecalin hydrocracking over palladium/zeolite-X, Fuel, 79, 13951404.

Suwannakarn K., Lotero, E., Ngaosuwan, K., and Goodwin, J.G., 2009, Simultaneous Free Fatty Acid Esterification and Triglyceride Transesterification Using a Solid Acid Catalyst with in situ Removal of Water and Unreacted Methanol, Industrial \& Engineering Chemistry Research, 48, 2810-2818.

Tiwari A. K., Kumar A., Raheman H, Biodiesel production from jatropha oil (Jatropha curcas) with high free fatty acids: an optimized process, Biomass and bioenergy, 2007, 31 (8), 569-575.

Vicente G., Martínez M., and Aracil J., 2007, Optimization of integrated biodiesel production, part I. a study of the biodiesel purity and yields, Bioresource Technology, 98, 1724 1733.

Wang L., and Yang J., 2007, Transesterification of soybean oil with nano-MgO or not in supercritical and subcritical methanol, Fuel, 86, 328-333.
Xie W. and Li, H., 2006. Alumina supported potassium iodide as a heterogeneous catalyst for biodiesel production from soybean oil. Journal of Molecular Catalysis A: Chemical, 255, 1-9.

Yujaroen D., Goto M., Sasaki M., and Shotipruk A., 2009, Esterification of palm fatty acid distillate (PFAD) in supercritical methanol : Effect of hydrolysis on reaction reactivity, Fuel, 88, 2011-2016. 